Article

\title{
Biofunctionalization of Textile Materials. 3. Fabrication of Poly(lactide)-Potassium Iodide Composites with Antifungal Properties
}

\author{
Marcin H. Kudzin *(D) and Zdzisława Mrozińska \\ The Lukasiewicz Research Network-Textile Research Institute, Brzezinska 5/15, 92-103 Lodz, Poland; \\ zmrozinska@iw.lodz.pl \\ * Correspondence: kudzin@iw.lodz.pl; Tel: +48-42-6163121
}

Received: 29 March 2020; Accepted: 19 June 2020; Published: 24 June 2020

\begin{abstract}
The paper presents a method of obtaining poly(lactide) (PLA) nonwoven fabrics with antifungal properties using potassium iodide as a nonwoven modifying agent. PLA nonwoven fabrics were obtained by the melt-blown technique and subsequently surface modified (PLA $\rightarrow$ PLA-SM-KI) by the dip-coating method. The analysis of these PLA-SM-KI $(0.1 \%-2 \%)$ composites included Scanning Electron Microscopy (SEM), UV/VIS transmittance, FTIR spectrometry and air permeability. The nonwovens were subjected to microbial activity tests against Aspergillus niger fungal mold species, exhibiting substantial antifungal activity. The studies showed that PLA-KI hybrids containing $2 \%$ KI have appropriate mechanical properties, morphology and demanded antimicrobial properties to be further developed as a potential antimicrobial, biodegradable material.
\end{abstract}

Keywords: poly(lactide); potassium iodide; poly(lactide)-potassium iodide composites; surface modification; polymer functionalization; antifungal activity

\section{Introduction}

Poly(lactide) (PLA) presents multifunctional applications in various medical areas. PLA hybrids with antibacterial additives (bactericide agents) display antiseptic properties, and therefore are applied in a variety of medical applications [1]. Thus, PLA itself presents a bioactive nanostructured matrix for controlled drug delivery or potential tissue engineering [1,2]. PLA hybrids with various ionic nanoparticles (e.g., PLA-Ag [3-5], PLA-CuSiO 3 [6], PLA-ZnO [7] and/or PLA-TiO 2 [8]) have strong antibacterial properties and can therefore be applied in biomedical and food packaging areas. PLA hybrids with antibiotics and drugs (PLA-ampicilline and PLA-metronidazole [9]; PLA-doxycycline [10]; PLA-chlorhexidine [11,12]; PLA-triclosan [12-15]) are a potential drug delivery system for use in periodontal and endodontic infections, treatment of persistent infections in medicine and dentistry, and also suitable for bone tissue engineering. As one group of such potential additives/components also halogen- and/or halogen-based compounds can be used-the most significant microbicides applied in the clinic and used traditionally for both antiseptic and disinfectant purposes [16].

Iodine is a highly effective topical antimicrobial agent that has been used clinically in the treatment of wounds for more than 170 years. It has a broad spectrum of antimicrobial activity with efficacy against bacteria, mycobacteria, fungi, protozoa and viruses and can be used to treat both acute and chronic wounds [16-18]. A unique feature of molecular iodine is certainly its ability to bind to polymeric materials. A variety of natural and synthetic polymers develop complexes when treated with molecular iodine, or with a mixture of molecular iodine and potassium iodide [19-24]. Iodophores-a group of disinfectants containing iodine, were developed in the 1950s to overcome side effects associated with 
elemental iodine. These were found to be safer and less painful, but just as effective as elemental iodine, allowing widespread use [18]. Starch iodophores can be used for technical and medical applications as the means of disinfection and components in cosmetics. Iodine can be bound to starch by forming an inclusion complex with amylose [19-22] or it can be immobilized into modified starch derivatives. The representative iodophores are shown in Figures 1-4.

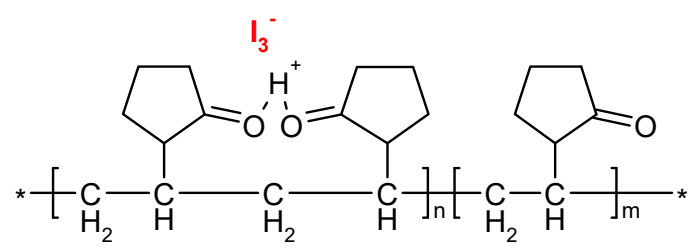

Figure 1. Structure of povidone-iodine (PVP-I) (polyvidone iodine, iodopovidone) [19].

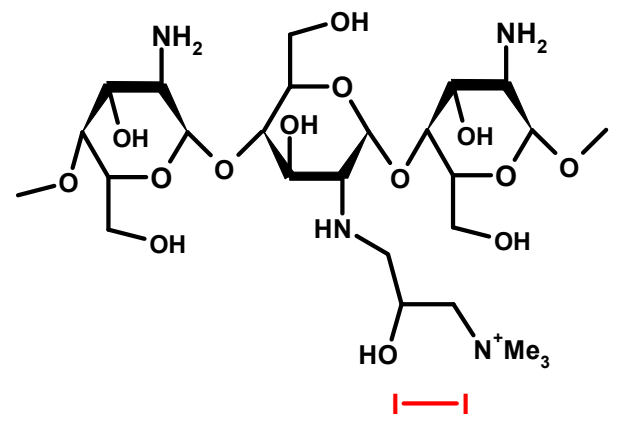

Figure 2. Structure of functionalized chitosan-iodine complex [24].

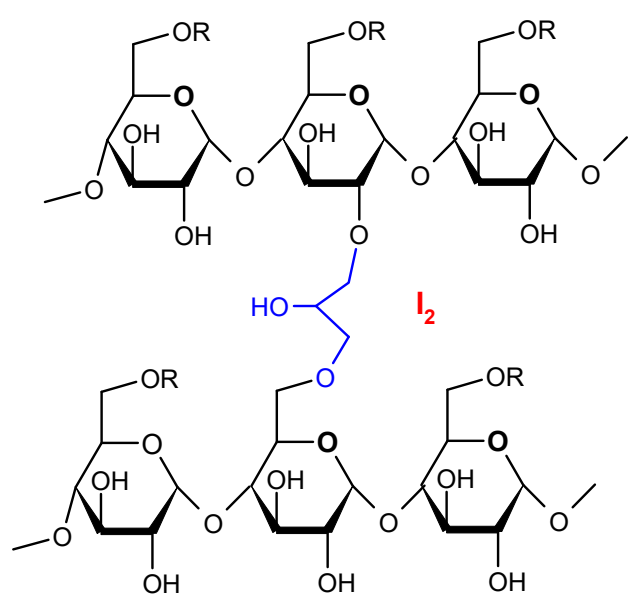

Figure 3. Structure of Cadexomer Iodine (2-hydroxy methylene cross-linked (1-4) $\alpha$-D-glucan ether containing iodine) [19].

Relatively rare are papers on the application of iodide salts for medical applications. These are in majority based on so called Photo Dynamic Inactivation [25,26] of iodides [27] by means of dye sensitizers (toluidine blue [28] and methylene blue [29], tetracyclines [30], eosine and rose Bengal [31], porphyrines (e.g., TPP [32], TP [33]) and/or inorganics [33,34] (e.g., $\mathrm{TiO}_{2}$ [35-37]), $\mathrm{FeCl}_{3}$ [38] and $\mathrm{H}_{2} \mathrm{O}_{2}-\mathrm{KI}$ and $\mathrm{H}_{2} \mathrm{O}_{2}-\mathrm{KI}-\mathrm{KSCN}[39,40]$ ). Also a few reports on antibacterial activity of iodides of quaternary ammonium salts derived from polymers (polymethacrylates (QAMA) [41], polyamidoamine dendrimers [42]), or chitosan [43] have been reported. 


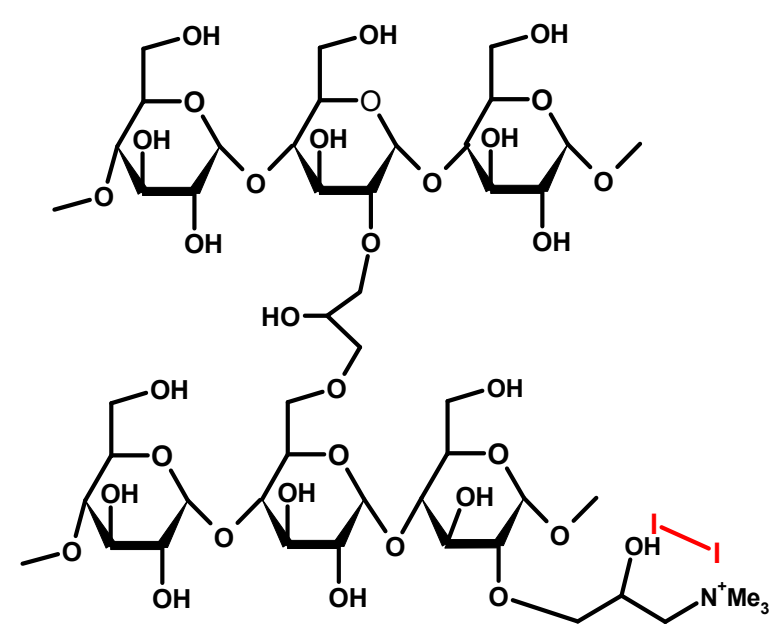

Figure 4. Structure of cationic starch iodophores [22,23].

As part of our research program on the functionalization of biomolecules [44-49], biopolymers and polymers [50-54], we present the preparation and biological exploration of a polymer hybrid based on polylactic (PLA) nonwoven fabric with surface modified by potassium iodide.

\section{Materials and Methods}

\subsection{Materials}

Polylactic acid (PLA) granulate was purchased from NatureWorks LLC (Minnetonka, MI, USA), type Ingeo ${ }^{\mathrm{TM}}$ Biopolymer $3251 \mathrm{D}, \mathrm{MFR}=30-40 \mathrm{~g} / 10 \mathrm{~min}\left(190^{\circ} \mathrm{C} / 2.16 \mathrm{~kg}\right), \mathrm{Tmp}=160-170{ }^{\circ} \mathrm{C}$, and was used to make samples of nonwovens;

Potassium iodide, $\geq 99 \%$, from Sigma-Aldrich (St. Louis, MO, USA) was used for surface modification of polymer nonwovens;

Lutexal Thickener HC - polyacrylate (PA), ammonia salt (BASF, Ludwigshafen, Germany) as a thickening agent;

Pluriol 600 — poly(ethylene glycol) (PEG) of molar mass 600 g/mol (BASF, Ludwigshafen, Germany) as a wetting agent;

Revacryl 247-styrene-acrylic ester copolymer (PS-PA) dispersion of low viscosity (Synthomer, Essex, UK).

Fungal Strains

Aspergillus niger van Tieghem (ATCC 6275) from Microbiologics (St. Cloud, MI, USA).

\subsection{Methods}

\subsubsection{Poly(lactide) Nonwoven Fabrics}

\section{Melt-Blown Technique}

PLA nonwovens were made by the melt-blown technique using a single-screw laboratory extruder (Axon, Sweden) with a head with 30 holes of $0.35 \mathrm{~mm}$ diameter each, compressed air heater and collecting drum. Dried to constant weight, PLA granules for melt-blown processing were fed into the extruder hopper. In a one-step process in which high-velocity air blows molten thermoplastic PLA polymer resin out of an extruder, a fibrous and self-bonding web is formed on the collecting drum. Nonwoven samples were made in the form of a sheet. The processing parameters for the production of PLA nonwoven are presented in Table 1. 
Table 1. Processing parameters used to prepare PLA composite nonwovens by the melt-blown technique.

\begin{tabular}{cc}
\hline \multicolumn{2}{c}{ Processing Parameters } \\
\hline Temperature of the extruder in zone 1 \\
Temperature of the extruder in zone 2 \\
Temperature of the extruder in zone 3 & $195^{\circ} \mathrm{C}$ \\
Head temperature & $245^{\circ} \mathrm{C}$ \\
Air heater temperature & $260^{\circ} \mathrm{C}$ \\
Air flow rate & $260^{\circ} \mathrm{C}$ \\
Polymer yields & $260^{\circ} \mathrm{C}$ \\
Mass per unit area of nonwovens & $7-8 \mathrm{~m}^{3} / \mathrm{h}$ \\
\hline
\end{tabular}

\subsubsection{Dip-Coating Modification}

Coating pastes homogeneously dispersed and of suitable viscosity (about 60-70 dPas) were prepared on the basis of styrene-acrylic resin (styrene-acrylic ester copolymer (PS-PA)), wetting agent (polyethylene glycol (PEG)), thickening agent (polyacrylate, ammonium salt (PA)) and aqueous solutions of KI $(0.1 \%, 1 \%$ or $2 \%$ aqueous solution). The components of the pastes of PLA surface modifier (SM) used, and corresponding modifier abbreviations are given in Table 2 . The nonwoven samples $(10 \mathrm{~cm} \times 10 \mathrm{~cm} ; 1.02 \pm 0.05 \mathrm{~g})$ were impregnated with the paste, squeezed and dried for $8 \mathrm{~h}$ at $60^{\circ} \mathrm{C}$ (to constant weight:1.14 $\pm 0.05 \mathrm{~g}$ ).

Table 2. Composition of the pastes of poly(lactide) (PLA) surface modifier (\%).

\begin{tabular}{|c|c|c|c|c|c|c|c|c|c|}
\hline \multirow{3}{*}{$\begin{array}{c}\text { Assignments for } \\
\text { Surface Modifiers } \\
\text { SM-KI }\end{array}$} & \multicolumn{5}{|c|}{ Paste Components (g) } & \multirow{2}{*}{\multicolumn{4}{|c|}{ Paste Components after Drying (\%) $c, c$}} \\
\hline & \multicolumn{3}{|c|}{ Polymeric Components ${ }^{a}$} & \multicolumn{2}{|c|}{$\begin{array}{l}\text { KI Aqueous } \\
\text { Solutions }\end{array}$} & & & & \\
\hline & PS-PA & PA & PEG & Water & $\mathrm{KI}^{\mathrm{b}}$ & PS-PA & PA & PEG & KI \\
\hline SM & 6 & 1 & 3 & 90 & - & 60 & 10 & 30 & - \\
\hline SM-KI(0.1) & 6 & 1 & 3 & 90 & 0.009 & 60 & 10 & 30 & 0.1 \\
\hline SM-KI(1) & 6 & 1 & 3 & 90 & 0.09 & 60 & 10 & 30 & 1 \\
\hline SM-KI(2) & 6 & 1 & 3 & 90 & 0.18 & 60 & 10 & 30 & 2 \\
\hline
\end{tabular}

a Styrene-acrylic resin (PS-PA); Thickening agent (PA); Wetting agent (PEG). ${ }^{\mathrm{b}}$ Amounts of KI in $100 \mathrm{~g}$ of water are $0.01,0.1$ and $0.2 \mathrm{~g}$, respectively. ${ }^{\mathrm{c}}$ Assuming full removal of water from a surface modifier layer. ${ }^{\mathrm{d}}$ Approximated to a first decimal place.

After modification, the nonwoven composites formed, assigned further as PLA-SM-KI (and PLA-SM for a composite of PLA and the coating paste without KI, respectively), presented visually uniform, homogeneous structure. The estimated compositions of so formed PLA-SM-KI composites were as follows: $\mathrm{PLA}=87.7 \%$; $\mathrm{PS}-\mathrm{PA}=8.4 \%$; $\mathrm{PA}=1.4 \% ; \mathrm{PEG}=4.2 \%$ and $\mathrm{KI}=0$ to $0.28 \%$.

\subsection{Instrumental Methods}

\subsubsection{SEM/EDS—Scanning Electron Microscopy/Energy-Dispersive X-ray Spectroscopy}

The microscopic analysis of fibers was performed on a Tescan Vega 3 scanning electron microscope (Brno, Czech Republic) with the EDS Oxford Instruments (Abingdon, UK) X-ray microanalyzer. The SEM microscopic examination of the surface topography was carried out under high vacuum using energy of the probe beam $20 \mathrm{ekV}$. The surface of each preparation was sprayed with a conductive substance (gold), using a vacuum dust extractor (Quorum Technologies Ltd., Lewes, UK). Magnification was from $500 \times$ to $20,000 \times$. 


\subsubsection{ATR-FTIR-Attenuated Total Reflectance Fourier-Transform Infrared Spectroscopy}

ATR-FTIR spectra were recorded at room temperature using a Jasco 4200 spectrometer (Tokyo, Japan) with Pike GladiATR attachment (Cottonwood, AZ, USA), in transmission mode in the range of $400-4000 \mathrm{~cm}^{-1}$.

\subsubsection{UV-VIS Analysis}

Changes in the physical properties such as the transmittance [\%T] of poly(lactide) nonwoven fabrics before (PLA and PLA-SM) and after KI incorporation (PLA-SM-KI) were assessed using a Jasco V-550 double-beam UV-VIS spectrophotometer with integrating sphere attachment in the range of 200-800 nm.

\subsubsection{Filtration Parameters}

Air permeability was determined for one layer of the nonwoven sample and the test based on EN ISO 9237:1998 standard [55]. An FX 3300 TEXTEST AG (Klimatest, Poland) permeability tester was used. Air at a pressure of 100 Pascal and 200 Pascal was passed through a fabric area of $20 \mathrm{~cm}^{2}$ diameter for testing. An average of 10 values was taken to be the final value of the sample.

\subsubsection{Tensile Testing}

Tensile testing of PLA, PLA-SM and PLA-SM-KI was carried out in accordance with EN ISO 10319:2015-08 standard [56]. A Tinius Olsen H50KS tester (Horsham, PA, USA) was used. Stretching speed was $20 \mathrm{~mm} / \mathrm{min}$.

\subsubsection{Antifungal Activity}

The antifungal activity of the resulting nonwoven fabrics was tested according to EN 14119: 2005 standard [57], against Aspergillus niger van Tieghem. Specimens of the tested material were placed on agar plates: samples of sterile PLA discs $(20 \mathrm{~mm})$ were charged with coating pastes with various amounts of potassium iodide (Table 3 ) and then the discs with PLA-SM-KI composites were placed on inoculated agar (pH:6.2) and incubated at $29^{\circ} \mathrm{C}$ for 14 days. The agar was inoculated with the selected fungus. Both sides of the nonwoven fabrics were tested. The level of antifungal activity was assessed by examining the extent of fungal growth: in the contact zone between the agar and the specimen, on the surface of specimens and, if present, the extent of the inhibition zone around the specimen. All tests were carried out in duplicate. Simultaneously, the same tests were carried out for control samples-samples of unmodified PLA nonwoven.

Table 3. Results of the Energy-Dispersive X-ray Spectroscopy (EDS) analysis of PLA, PLA surface modifier (SM) and PLA-SM potassium iodide (KI) (2\%).

\begin{tabular}{ccccccccc}
\hline Fiber/Composite & \multicolumn{2}{c}{ PLA } & \multicolumn{2}{c}{ PLA-SM } & \multicolumn{3}{c}{ PL-SM-KI (2\%) } \\
\hline Atom & C & O & C & O & C & O & K & I \\
\hline$\%^{\text {a }}$ & 51.7 & 48.33 & 60.08 & 39.92 & 57.11 & 41.28 & 0.35 & 1.25 \\
\hline Std. deviation & 0.11 & 0.11 & 0.29 & 0.29 & 1.10 & 1.02 & 0.01 & 0.09 \\
\hline \multicolumn{8}{c}{ a Mean value of 3 measurements. }
\end{tabular}

\section{Results and Discussion}

\subsection{SEM/EDS—Scanning Electron Microscopy/Energy-Dispersive X-ray Spectroscopy}

Scanning electron microscopy (SEM) is a routine technique for morphological tests of poly(lactide) nonwovens, including both electrospun PLA [58,59] as well as melt-blown PLA [60-63] fibers. SEM micrographs of uncoated PLA fibers, coated without KI (PLA-SM) fibers and coated with 2\% potassium iodide (PLA-SM-KI (2\%)) fibers are presented in Figures 5-7, respectively. 


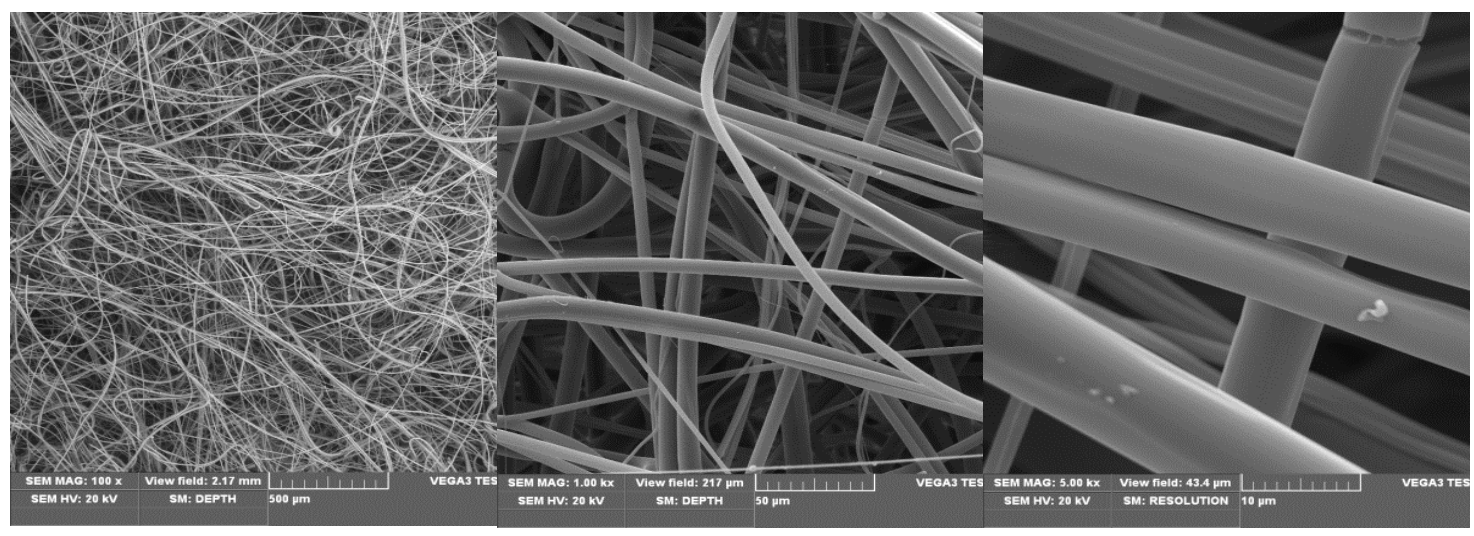

(a)

(b)

(c)

Figure 5. SEM images of starting PLA, magnification: $100 \times(\mathbf{a}), 1000 \times(\mathbf{b})$ and $5000 \times(\mathbf{c})$. (a) (SEM mag.×100). (b) (SEM mag.×1000). (c) (SEM mag.×5000).

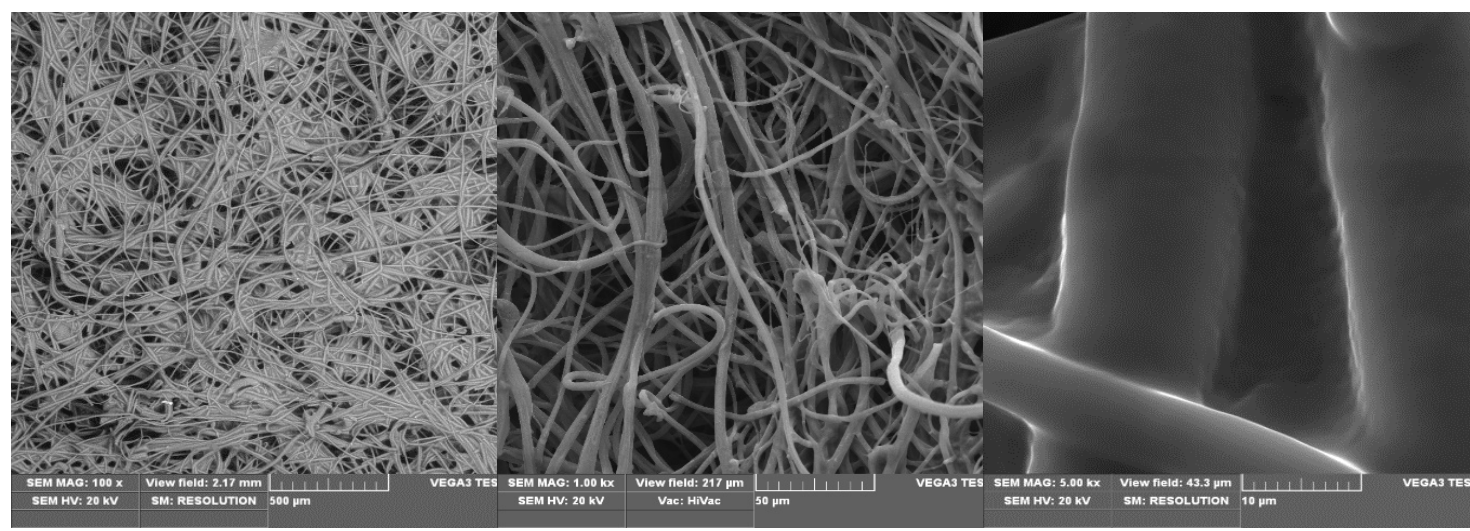

(a)

(b)

(c)

Figure 6. SEM images of PLA-SM composite, magnification: $100 \times(\mathbf{a}), 1000 \times(\mathbf{b})$ and $5000 \times(\mathbf{c})$. (a) (PLA-SM; SEM mag.×100). (b) (PLA-SM; SEM mag.×1000). (c) (PLA-SM; SEM mag.×5000).

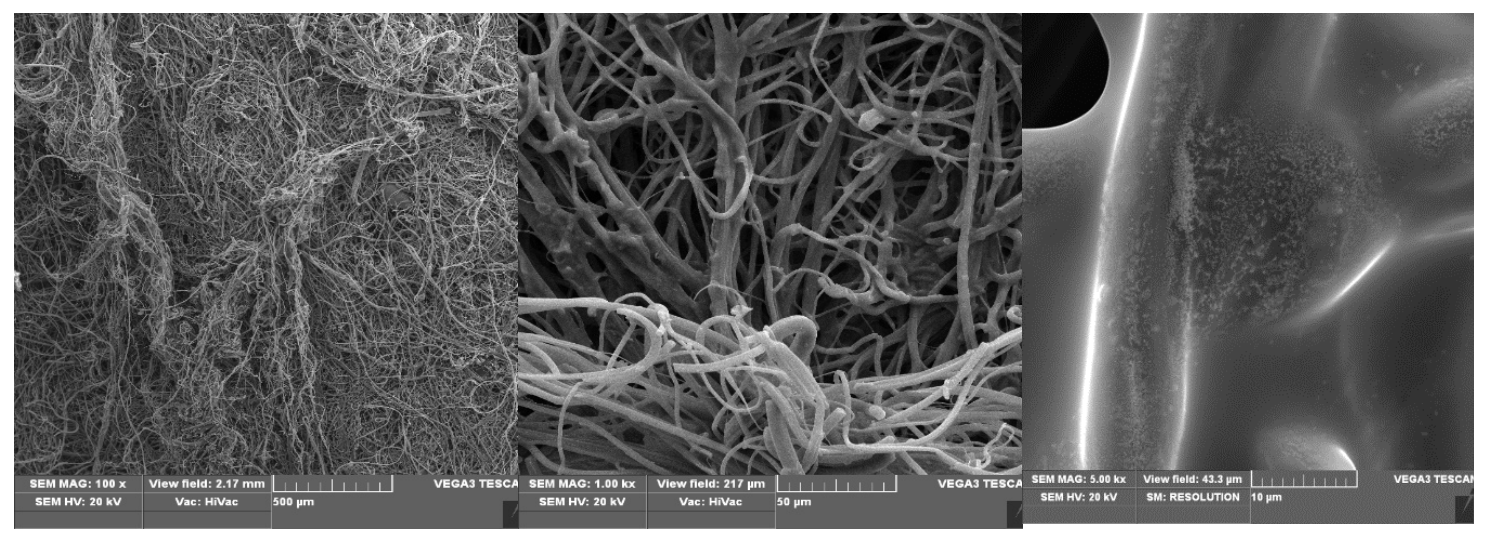

(a)

(b)

(c)

Figure 7. SEM images of PLA-SM-KI (2\%) composite, magnification: $100 \times(\mathbf{a}) ; 1000 \times(\mathbf{b})$ and $5000 \times(\mathbf{c})$. (a) (PLA-SM-KI (2\%); SEM mag.×100). (b) (PLA-SM-KI (2\%); SEM mag.×1000). (c) (PLA-SM-KI (2\%); SEM mag.×5000).

SEM images of PLA nonwovens show uniform, randomly oriented fibers, with interconnected pores (space) between nanofibers and a relatively smooth surface. The average diameters of PLA fibers applied ranged from 1.4 to $8.5 \mu \mathrm{m}$ (Figure 5c). Morphological changes in PLA after surface deposition 
of a modifier (PLA $\rightarrow$ PLA-SM), observed in Figure 6, illustrate the formation of fiber conglomerates with a rough surface. SEM images of PLA covered with a surface modifier and KI (PLA-SM-KI $(2 \%)$ ) additionally reveal some dots on the modifier surface, presumably KI crystals (e.g., Figure 7c).

Results of the EDS analysis of PLA, PLA-SM and PLA-SM-KI are presented in Table 3. The content of carbon and oxygen components of PLA (without hydrogen) is similar to the atomic "bulk" analysis of PLA $(C=50.0 \%$ and $\mathrm{O}=44.4 \%)$. The surface modification of PLA using a surface modifier (the mixture of PS-PA $(60 \%)$, PEG $(30 \%)$ and PA( $\left.\mathrm{NH}_{4}\right)(10 \%)$ leads to the appearance of a more carbonaceous layer. The EDS analysis of PLA-SM-KI (2\%) hybrid exhibits the appearance of KI in the analyzed sample (ca. 1.6\%) corresponding to the KI content calculated in Table 1 (KI content in the hybrid assuming full water removal during paste drying). The results of carbon (decrease in carbon content $\sim 3 \%$ ) and oxygen (increase by $1.36 \%$ ) can be obtained from the appearance of KI $(1.6 \%)$ and the presence of residual water in the layer of the surface modifier.

\subsection{ATR-FTIR}

Comparison of ATR-FTIR spectra of poly(lactide) nonwoven (PLA), and poly(lactide) nonwoven charged with a surface modifier (PLA-SM) and charged with a surface modifier containing potassium iodide (PLA-SM-KI (2\%)), and potassium iodide (KI) is shown in Figure 8 (range 4000-400 $\mathrm{cm}^{-1}$ ) and Figure 9 (range 1800-1400 $\mathrm{cm}^{-1}$ ). Characteristic FTIR bands described for a poly(lactide) nonwoven sample (PLA) and components of PLA-SM-KI composite, namely poly(lactide) (PLA), polyacrylate (PA), polyglycol (PEG), polystyrene (PS) and potassium iodide (KI) are presented in Table 4. Characteristic FTIR bands $\left(v /\left[\mathrm{cm}^{-1}\right]\right)$ determined for PLA, PLA-SM, PLA-SM-KI ( $\left.2 \%\right)$ and KI are listed in Table 5.

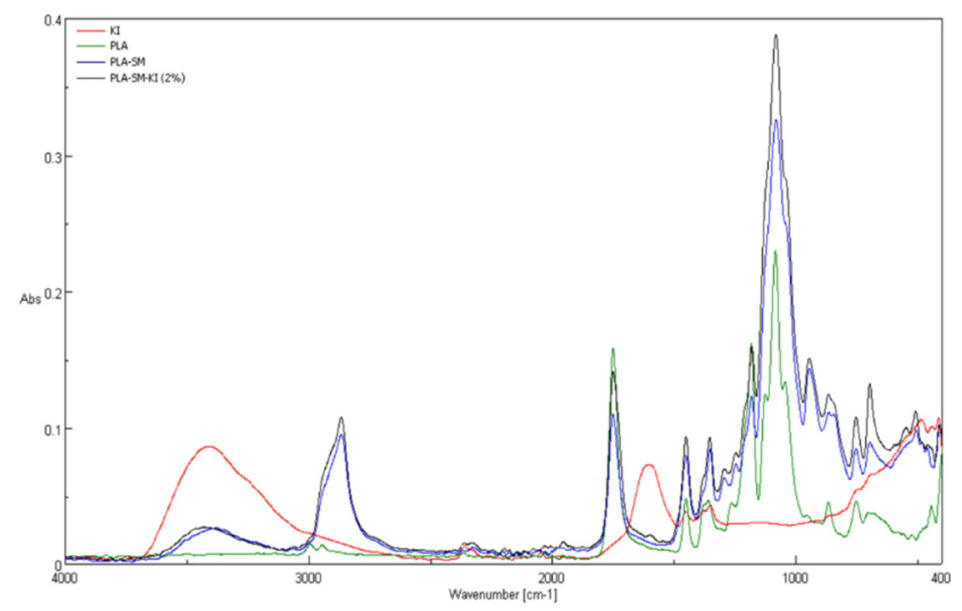

Figure 8. Attenuated Total Reflectance Fourier-Transform Infrared Spectroscopy (ATR-FTIR) spectra of PLA, PLA-SM, PLA-SM-KI (2\%) and KI, range $400-4000 \mathrm{~cm}^{-1}$.

The investigated compositions of PLA-SM-KI present multi-component mixtures with dominated content of PLA matrix (ca. 88\%), lower contents of polymeric components of the surface modifier, namely PS-PA (8.4\%); PEG (4.2\%) and PA (1.4\%), and small to negligible content of KI (0 to $0.28 \%$ ) calculated as the bulk content. Therefore, the IR spectra of these composites present the average of the individual contribution of functional groups that existed in these polymeric constituents (and KI). Thus, bands of high absorbance are these derived from ester group [63], namely at $1750 \mathrm{~cm}^{-1}(\mathrm{vCO})$, appearing in PLA (abs. 0.16), PLA-SM (abs. 0.11) and PLA-SM-KI (2\%) (abs. 0.14) and $1084 \mathrm{~cm}^{-1}$ ( $v C O C)$, appearing in PLA (abs. 0.23), PLA-SM (abs. 0.33) and PLA-SM-KI (abs. 0.39) spectra. A non-bonded hydroxyl group, derived from water/moisture absorbed, can be assigned to broad bands appearing at $3400 \pm 200 \mathrm{~cm}^{-1}$ in KI (abs. 0.09), PLA-SM (abs. 0.05) and PLA-SM-KI (abs. 0.06) spectra. These bands were also found in the literature data for PA [64], PEG [65,66], PS [67], and KI [68]. The bands at $1451 \mathrm{~cm}^{-1}$ appearing in PLA (abs. 0.05; $\delta_{\mathrm{as}} \mathrm{CH}_{3}$ ), PLA-SM (abs. 0.08) and PLA-SM-KI (abs. 0.10) can be assigned to overlapping signals derived from $\delta_{\mathrm{as}} \mathrm{CH}_{3}$ of PLA [69]; aromatic stretching 
vibration $v_{\text {ar. str. }} \mathrm{C}=\mathrm{C}$ of PS [67], and $\mathrm{CH}_{2}$ (scission vibration) of PG [65,66]. At $1455 \mathrm{~cm}^{-1}$, a signal appeared derived from KI (abs. 0.04). At the region 1500-800 $\mathrm{cm}^{-1}$ appeared several overlapping signals derived from PLA, PS, PEG and PA, however dominated by PLA signals, due to its contents in the composite.

The IR spectrum of PLA-SM-KI ( $2 \%)$ composite reveals three new distinct bands compared with PLA. The first one presents a broad band at $3600-3100 \mathrm{~cm}^{-1}$, (derived from water [69]) similar to those exhibited in the PLA-SM spectrum (occurring in PA and PEG IR spectra), and also exhibited in the KI spectrum (due to water contents). The second band occurring at $2900 \mathrm{~cm}^{-1}$ also occurring in PLA-SM spectrum, may be derived from the polystyrene content of the surface modifier (Table 4). The third band appearing at $1600 \mathrm{~cm}^{-1}$ presents the second major band of KI (Figure 9) in the KI spectrum.

Table 4. Characteristic FTIR bands of components of PLA-SM-KI composite quoted in the literature.

\begin{tabular}{|c|c|c|c|c|}
\hline \multicolumn{5}{|c|}{$\begin{array}{c}\text { IR Vibration Bands }\left[v / \mathrm{cm}^{-1}\right]_{\text {for PLA-SM-KI Hybrid Components (Name, Abbreviation, Structure }} \\
{\left[\text { [Literature]) }^{a}\right.}\end{array}$} \\
\hline $\begin{array}{l}\text { Polylactide (PLA) } \\
{[63]}\end{array}$ & $\begin{array}{l}\text { Polyacrylate (PA) } \\
{[64]}\end{array}$ & $\begin{array}{l}\text { Polyglycol (PEG) } \\
{[65,66]}\end{array}$ & $\begin{array}{l}\text { Polystyrene (PS) } \\
{[67]}\end{array}$ & $\begin{array}{l}\text { Potassium Iodide } \\
\text { (KI) [68] }\end{array}$ \\
\hline 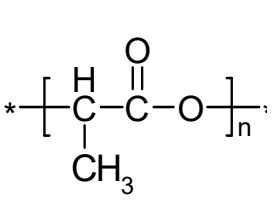 & 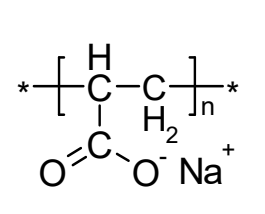 & $\left.* \underset{\mathrm{H}_{2}}{\mathrm{C}}-\underset{\mathrm{H}}{\mathrm{H}}-\mathrm{O}-\right]_{\mathrm{n}}$ & $-\underset{\mathrm{H}_{2}}{\mathrm{C}} \frac{\mathrm{l}}{\mathrm{n}}$ * & $\mathrm{K}^{+} \mathrm{I}^{-}$ \\
\hline- & $3700-2900$ & 3500 & 3447 & 3435 \\
\hline & - & - & 3060 & - \\
\hline 2997 & - & - & 3026 & - \\
\hline 2947 & - & 2934 & 2922 & - \\
\hline - & - & - & 2848 & - \\
\hline 1760 & 1750 & - & - & - \\
\hline - & 1651 & - & - & - \\
\hline - & - & - & 1600 & 1623 \\
\hline - & 1577 & - & - & - \\
\hline - & - & - & 1493 & - \\
\hline 1452 & - & 1466 & 1452 & - \\
\hline $1348-1388$ & - & - & - & 1399 \\
\hline $1368-1360$ & - & 1341 & - & - \\
\hline 1270 & - & 1278 & - & - \\
\hline 1215 & - & 1241 & - & - \\
\hline 1185 & - & 1145 & - & - \\
\hline 1130 & - & - & - & - \\
\hline 1100 & - & 1097 & - & - \\
\hline 1090 & - & - & - & - \\
\hline 1045 & - & 1058 & - & 1042 \\
\hline - & - & 960 & - & - \\
\hline - & 800 & 840 & - & - \\
\hline - & & - & 756 & - \\
\hline - & & - & 698 & - \\
\hline 538 & & - & 538 & - \\
\hline
\end{tabular}

a Vibration band assignments as given in Refs. [63-68]. 
Table 5. Characteristic FTIR bands $\left(v /\left[\mathrm{cm}^{-1}\right]\right)$ determined for PLA, PLA-SM, PLA-SM-KI $(2 \%)$ and KI.

\begin{tabular}{|c|c|c|c|c|c|c|c|}
\hline \multicolumn{8}{|c|}{ Composites and Components } \\
\hline \multicolumn{2}{|c|}{ PLA } & \multicolumn{2}{|c|}{ KI } & \multicolumn{2}{|c|}{ PLA-SM } & \multicolumn{2}{|c|}{ PLA-SM-KI (2\%) } \\
\hline$v\left[\mathrm{~cm}^{-1}\right]$ & Absorb. ${ }^{a}$ & $v\left[\mathrm{~cm}^{-1}\right]$ & Absorb. ${ }^{a}$ & $v\left[\mathrm{~cm}^{-1}\right]$ & Absorb. $^{\mathrm{a}}$ & $v\left[\mathrm{~cm}^{-1}\right]$ & Absorb. ${ }^{a}$ \\
\hline- & - & $3680-2800$ & 0.09 & $3600-3100$ & 0.05 & $3600-3100$ & 0.06 \\
\hline 2993 & 0.01 & - & - & - & - & - & - \\
\hline 2944 & 0.01 & - & - & - & - & - & - \\
\hline- & - & - & - & 2863 & 0.09 & 2867 & 0.11 \\
\hline- & - & 2362 & 0.01 & - & - & - & - \\
\hline- & - & 2184 & 0.01 & - & - & - & - \\
\hline- & - & 2041 & 0.01 & - & - & - & - \\
\hline 1749 & 0.16 & - & - & 1751 & 0.11 & 1751 & 0.14 \\
\hline- & - & 1602 & 0.07 & - & - & 1602 & 0.02 \\
\hline 1451 & 0.05 & 1455 & 0.04 & 1451 & 0.08 & 1451 & 0.10 \\
\hline 1359 & 0.05 & 1352 & 0.04 & 1353 & 0.08 & 1353 & 0.10 \\
\hline 1186 & 0.16 & - & - & 1184 & 0.12 & 1178 & 0.16 \\
\hline 1084 & 0.23 & - & - & 1083 & 0.33 & 1083 & 0.39 \\
\hline- & - & - & - & 943 & 0.14 & 943 & 0.15 \\
\hline 864 & 0.05 & - & - & 862 & 0.11 & 862 & 0.13 \\
\hline 750 & 0.05 & - & - & 751 & 0.08 & 751 & 0.11 \\
\hline 695 & 0.04 & - & - & 693 & 0.09 & 696 & 0.14 \\
\hline- & - & - & - & 507 & 0.98 & 511 & 0.11 \\
\hline- & - & 485 & 0.11 & - & - & - & - \\
\hline 442 & 0.04 & - & - & - & - & - & - \\
\hline
\end{tabular}

${ }^{a}$ Absorbance values approximated to a second decimal place.

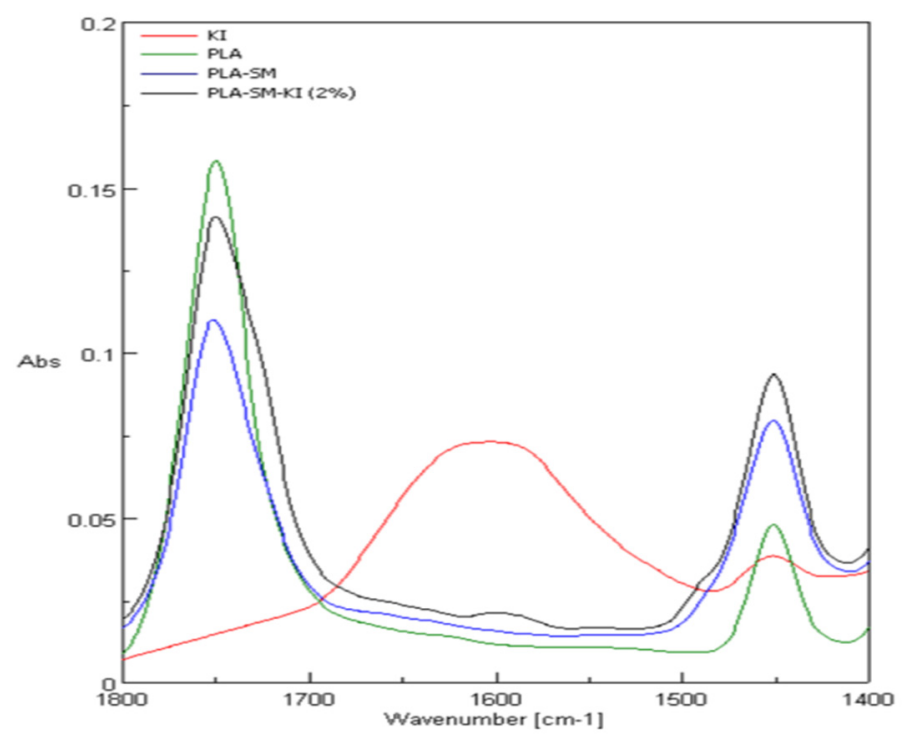

Figure 9. ATR-FTIR spectra of PLA, PLA-SM, PLA-SM-KI (2\%) and KI, range $1400-1800 \mathrm{~cm}^{-1}$. 


\subsection{UV/VIS Transmittance Spectra}

The UV/VIS transmittance spectra $T=f(\lambda)$ (T [\%] vs. $\lambda$ [nm]) of PLA, PLA-SM and PLA-SM-KI $(0.1-2 \%)$ fibers/composites were recorded. The spectra of PLA, PLA-SM and PLA-SM-KI (2\%) fibers/composites are presented in Figure 10.

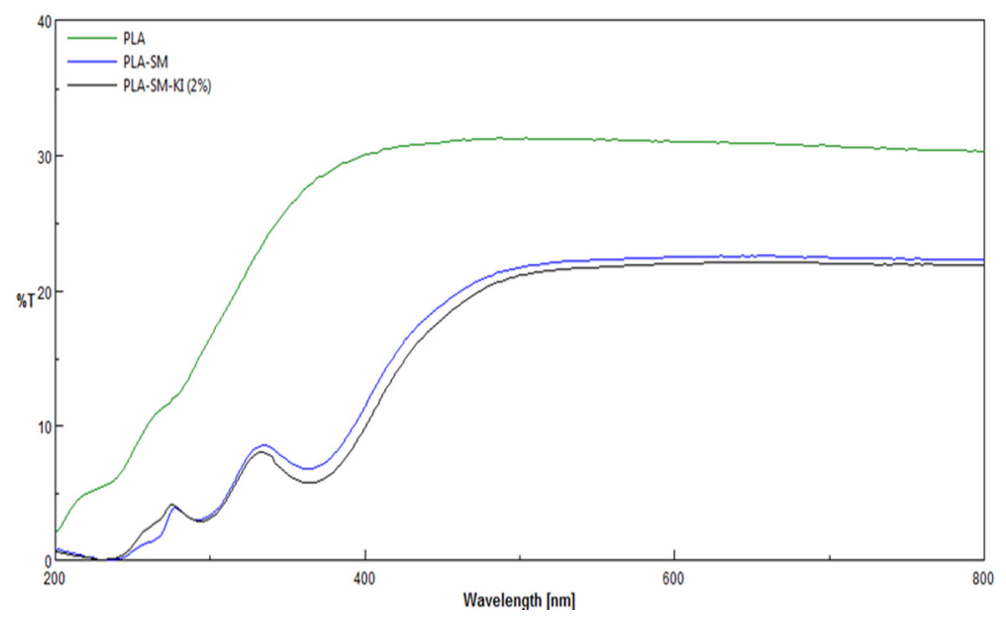

Figure 10. Comparison of UV/VIS transmittance spectra $T=f(\lambda)$ (T [\%] vs. $\lambda$ [nm]) of PLA, PLA-SM and PLA-SM-KI (2\%), recorded in the range $\lambda=200-800 \mathrm{~nm}$.

The UV/VIS spectra analysis of PLA, PLA-SM and PLA-SM-KI revealed:

Decrease of transmittance ability in the whole range of measurements ([T] $]_{(\operatorname{PLA}(\max ))}: 32 \%$ for $500 \mathrm{~nm},\left([T]_{(\mathrm{PLA}-S M(\max ))}: 700 \mathrm{~nm}-23 \%\right)$ related to morphological changes of PLA after surface deposition of the modifier (PLA-SM and/or PLA-SM-KI), namely the formation of spots and fiber conglomerates on the original surface of starting PLA;

Appearance of peaks at 251 and $349 \mathrm{~nm}$, resulting from the surface modification of starting polylactide. These peaks are the same in PLA-SM and PLA-SM-KI, and therefore can be assigned to polymeric components of the coating paste (SM).

\subsection{Technical Parameters}

Filtration parameters expressed by air permeability were detected for (PLA), and nonwovens coated with a surface modifier (PLA-SM) and a surface modifier with potassium iodide (PLA-SM-KI) (Table 6).

Table 6. Air flow resistance of PLA, PLA-SM and PLA-SM-KI (2\%), according to EN ISO 9237:1998. [55].

\begin{tabular}{rcccccc}
\hline Parameter & & PLA & PLA-SM & \multicolumn{3}{c}{ PLA-SM-KI (KI Paste Concentr. [\%]) } \\
\cline { 3 - 7 } & & & - & $\mathbf{0 . 1} \%$ & $\mathbf{1 \%}$ & $\mathbf{2 \%}$ \\
\hline $\begin{array}{c}\text { Average air permeability } \\
{[\mathrm{mm} / \mathrm{s}] \text {, pressure decrease: }}\end{array}$ & $100 \mathrm{~Pa}$ & 905 & 428 & 430 & 420 & 435 \\
\cline { 2 - 7 } & $200 \mathrm{~Pa}$ & 1640 & 825 & 820 & 831 & 825 \\
\hline
\end{tabular}

The parameters were measured in triplicate and presented as a mean value with \pm deviation of about $1 \%$.

The results of air flow resistance of modified poly(lactide) showed that:

A significant decrease of air permeability in the investigated fibers (from $905 \mathrm{~mm} / \mathrm{s}$ (for PLA) to about $428 \mathrm{~Pa}$ (for PLA-SM) at $100 \mathrm{~Pa}$, and from $1640 \mathrm{~mm} / \mathrm{s}$ (for PLA) to $825 \mathrm{~Pa}$ (for PLA-SM) at $200 \mathrm{~Pa}$, respectively);

Negligible effect of potassium iodide content in the coating paste on the filtration properties of synthesized PLA-SM-KI composites. 
These data lead to the conclusion that the observed decrease in PLA-modified air permeability is caused by the formation of a new surface layer on PLA (PLA-SM), derived from the applied surface coating mixture (PA, PS-PA, PEG) (Table 2).

The results of the tests, including tensile strength $[\mathrm{kN} / \mathrm{m}]$ and relative elongation at maximum load [\%] of PLA nonwoven fabrics and PLA-SM-KI composite are given in Table 7.

Table 7. Results of tensile strength test of PLA, PLA-SM and PLA-SM-KI $(0.1 \%-2 \%)$ composites, according to EN ISO 10319:2015-08 standard. Textiles. [56].

\begin{tabular}{cccccc}
\hline \multirow{2}{*}{ Parameter } & PLA & PLA-SM & \multicolumn{3}{c}{ PLA-SM-KI } \\
\cline { 4 - 6 } & & & $\mathbf{0 . 1 \%}$ & $\mathbf{1 \%}$ & $\mathbf{2 \%}$ \\
\hline Tensile strength $[\mathrm{kN} / \mathrm{m}]$ & 0.030 & 0.11 & 0.11 & 0.11 & 0.11 \\
\hline $\begin{array}{c}\text { Relative elongation at } \\
\text { maximum load [\%] }\end{array}$ & 10.0 & 10.6 & 10.6 & 11.7 & 10.8 \\
\hline
\end{tabular}

The parameters were measured in triplicate and presented as a mean value with \pm deviation of about $1 \%$.

The results of tensile strength tests revealed:

The improvement of technical properties for PLA-SM-KI in comparison with PLA, namely a distinct increase in tensile strength $(0.30$ to $0.112(\mathrm{kN} / \mathrm{m}))$ and slow in relative elongations $(10.0 \%$ to $11.0 \%$, respectively;

The negligible effect of KI concentration on the tensile strength of the modified samples;

A new composite PLA-SM-KI has a more flexible and stronger structure than unmodified PLA fabrics;

The changes in tensile strength between the PLA-SM and PLA are a result of the incorporation of a layer of the modifying paste (SM) in the PLA fiber structure (Figure 6), which causes higher stability and strength of the PLA-SM-KI composites.

\subsection{Antifungal Activity}

The PLA, PLA-SM and PLA-SM-KI (0.1-2\%) nonwoven/hybrids were subjected to antifungal activity tests against a colony of Aspergillus niger (ATCC 6275) [57,70,71] (Table 8). Results of these studies gave new biofunctionalized materials, which provide antimicrobial protection against fungal microorganisms.

Table 8. Results of tests on the antifungal activity of modified nonwovens.

\begin{tabular}{cccccccc}
\hline \multicolumn{7}{c}{ Fungal Average Inhibition Zone (mm) } \\
\hline \multicolumn{7}{c}{ KI concentrations in applied SM-KI (\%) } \\
\hline \multicolumn{7}{c}{0.1} & \multicolumn{2}{c}{1} \\
\hline \multicolumn{7}{c}{ Side of the sample } \\
\hline 1 & 2 & 1 & 2 & 1 & 2 & 1 & 2 \\
\hline 0 & 0 & 6 & 7 & Nvg & Nvg & Nvg & Nvg \\
\hline
\end{tabular}

Inoculum concentration, number of fungal spores in $1 \mathrm{~mL}(\mathrm{CFU} / \mathrm{mL})=2.8 \times 10^{6}$ (determined using a Thoma chamber). NVG—no visible growth.

Amounts of $1-2 \%$ of potassium iodide in coating pastes (PLA-SM-KI (1-2\%)) provided the antimicrobial properties for Aspergillus niger, expressed by the lack of visible growth under a microscope (50× magnification). PLA-SM exhibits strong growth covering the entire surface of the control sample (Table 7, Figure 11). Additionally, the applied surface modification of the PLA fibers did not affect any tested mechanical properties of PLA-SM-KI hybrids, synthesized. 


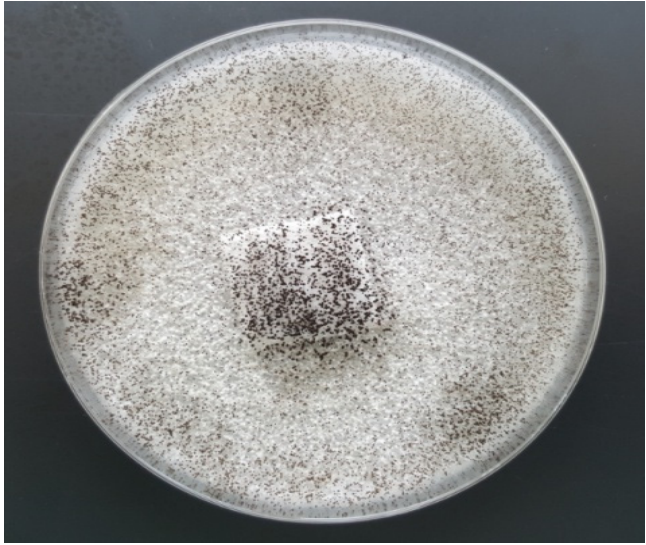

(a)

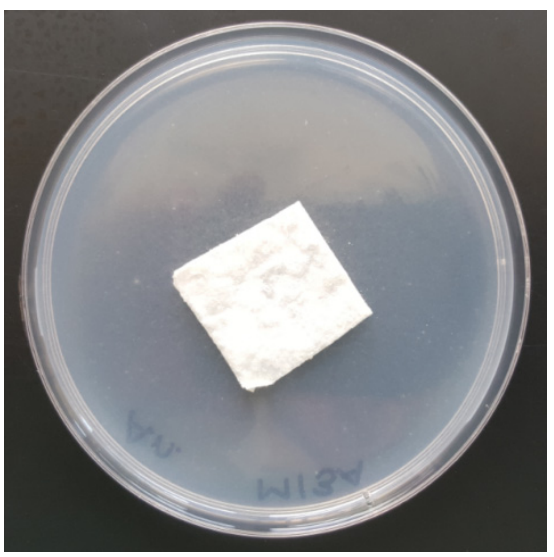

(c)

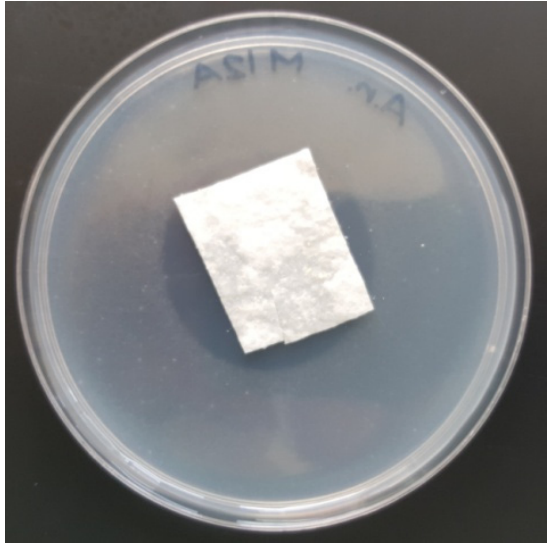

(b)

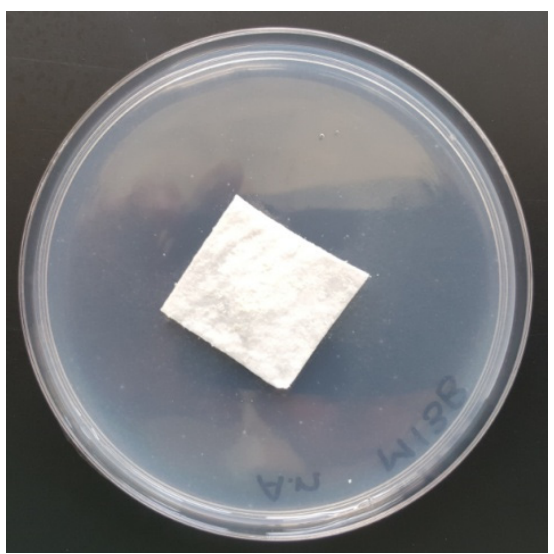

(d)

Figure 11. The antimicrobial activity tests of PLA-SM and PLA-SM-KI composites against Aspergillus niger. Inhibition zones of bacterial growth on Petri dishes. PLA-SM-KI composites (with KI coating paste concentrations: $0 \%, 0.1 \%, 1 \%$ and $2 \%$ ): (a) PLA-SM; (b) PLA-SM-KI (KI = 0.1\%); (c) PLA-SM-KI (KI = 1\%); (d) PLA-SM-KI (KI = 2\%).

These results are comparable with those for an effective iodide formulation for killing Bacillus and Geobacillus spores (optimum for $0.075 \mathrm{mM}(\sim 1.4 \%)$ of KI; $\mathrm{pH}=0.3)$ presented by Kida et al. [38], however in mild conditions and on the PLA coating surface.

The results of antifungal investigations of PLA-MS-KI revealed that:

PLA-SM nonwoven fabrics (without KI) exhibited strong growth-covering of the entire surface of the control sample;

Incorporation of potassium iodide into the nonwoven structure (PLA $\rightarrow$ PLA-MS $\rightarrow$ PLA-MS-KI) provided antifungal properties of the new composite (Table 7: Sample 1 vs. 2, 3, 4);

PLA-MS-KI with KI $\geq 1 \%$ exhibited antimicrobial properties for Aspergillus niger, expressed by no visible growth under the microscope (50× magnification);

At the same time, the surface modification of the nonwovens with potassium iodide (PLA $\rightarrow$ PLA-MS $\rightarrow$ PLA-MS-KI) did not show any impact on the mechanical properties of the modified textile.

\section{Conclusions}

Medicine, especially at present, is focused on the search for new and more effective methods of combating pathogens and antigens such as viruses, bacteria and fungi. In recent years there has been growing interest in biodegradable, "eco-friendly" and multifunctional polymers that can be used in selected biomedical applications. This paper presents a method for functionalization of 
poly(lactide) nonwoven fabrics by a potassium iodide modifier. The PLA-SM-KI's are eco-friendly composites, and easily biodegradable PLA consists as their major component (ca. 88\%). The structural properties of these new products have been characterized by Scanning Electron Microscopy, Attenuated Total Reflectance Fourier-transform Infrared and Ultraviolet-Visible Spectrophotometry, their technical/application feature has been positively verified during their air permeability tests and tensile testing. The revealed antifungal activity against Geobacillus spores makes them compatible with the literature antimicrobials, based on iodide/iodine. Important features of the coating process presented include easy implementation on an industrial scale, possibility to quickly start a simple production line and low production costs. All materials used in this work are commercially available and relatively cheap. The pronounced antimicrobial potency of the composite materials presented suggests that PLA-SM-KI should be considered as an antiseptic agent in a wide spectrum of biomedical applications.

Author Contributions: M.H.K. designed the research study and contributed to the data interpretation and to the manuscript drafting and revisions, analyzed the data and contributed to writing the manuscript. Z.M. analyzed the data and participated in preparation of the publication. All authors have read and agreed to the published version of the manuscript.

Funding: This research was funded by the Polish Ministry of Science and Higher Education within statutory research work carried out at The Lukasiewicz Research Network-Textile Research Institute, Lodz, Poland.

Acknowledgments: The authors would like to thank Irena Kamińska, for performing SEM and EDS analyses.

Conflicts of Interest: The authors declare no conflict of interest.

\section{References}

1. Auras, R.; Lim, L.T.; Selke, S.E.M. Poly(Lactic Acid): Synthesis, Structures, Properties, Processing, and Applications; Tsuji, H., Ed.; John Wiley \& Sons, Inc.: Hoboken, NJ, USA, 2010.

2. Zhou, J.; Han, S.; Dou, Y.; Lu, J.; Wang, C.; He, H.; Li, X.; Zhang, J. Nanostructured poly(l-lactide) matrix as novel platform for drug delivery. Int. J. Pharm. 2013, 448, 175-188. [CrossRef]

3. Wang, H.; Wei, Q.; Wang, X.; Gao, W.; Zhao, X. Antibacterial properties of PLA nonwoven medical dressings coated with nanostructured silver. Fiber Polym. 2008, 9, 556-560. [CrossRef]

4. Sun, Z.; Fan, C.; Tang, X.; Zhao, J.; Song, Y.; Shao, Z.; Xu, L. Characterization and antibacterial properties of porous fibers containing silver ions. Appl. Surf. Sci. 2016, 387, 828-838. [CrossRef]

5. Martínez-Abad, A.; Ocio, M.J.; Lagaron, J.M. Morphology, physical properties, silver release, and antimicrobial capacity of ionic silver-loaded poly(L-lactide) films of interest in food-coating applications. J. Appl. Polym. Sci. 2014, 131, 41001. [CrossRef]

6. Sójka-Ledakowicz, J.; Chruściel, J.J.; Kudzin, M.H.; Łatwińska, M.; Kiwała, M. Antimicrobial functionalization of textile materials with copper silicate. Fibres Text. East. Eur. 2016, 24, 151-156. [CrossRef]

7. Virovska, D.; Paneva, D.; Manolova, N.; Rashkov, I.; Karashanova, D. Electrospinning/electrospraying vs. electrospinning: A comparative study on the design of poly(l-lactide)/zinc oxide non-woven textile. Appl. Surf. Sci. 2014, 311, 842-850. [CrossRef]

8. Toniatto, T.V.; Rodrigues, B.V.M.; Marsi, T.C.O.; Ricci, R.; Marciano, F.R.; Webster, T.J.; Lobo, A.O. Nanostructured poly(lactic acid) electrospun fiber with high loadings of $\mathrm{TiO}_{2}$ nanoparticles: Insights into bactericidal activity and cell viability. Mater. Sci. Eng. C Mater. Biol. Appl. 2017, 71, 381-385. [CrossRef] [PubMed]

9. Schkarpetkin, D.; Reise, M.; Wyrwa, R.; Völpel, A.; Berg, A.; Schweder, M.; Schnabelrauch, M.; Watts, D.C.; Sigusch, B.W. Development of novel electrospun dual-drug fiber mats loaded with a combination of ampicillin and metronidazole. Dent. Mater. 2016, 32, 951-960. [CrossRef] [PubMed]

10. Cui, S.; Sun, X.; Li, K.; Gou, D.; Zhou, Y.; Hu, J.; Liu, Y. Polylactide nanofibers delivering doxycycline for chronic wound treatment. Mat. Sci. Eng. C 2019, 104, 109745. [CrossRef]

11. Luo, D.; Zhang, X.; Shahid, S.; Cattel, M.J.; Gould, D.J.; Sukhorukov, G.B. Electrospun poly(lactic acid) fibers containing novel chlorhexidine particles with sustained antibacterial activity. Biomater. Sci. 2016, 5, 111-119. [CrossRef]

12. Olmo, C.; Franco, L.; del Valle, L.J.; Puiggalí, J. Preparation of medicated polylactide micropieces by means of ultrasonic technology. Appl. Sci. 2019, 9, 2360. [CrossRef] 
13. Davachi, S.M.; Kaffashi, B.; Zamanian, A.; Torabinejad, B.; Ziaeirad, Z. Investigating composite systems based on poly L-lactide and poly L-lactide/triclosan nanoparticles for tissue engineering and medical applications. Mater. Sci. Eng. C Mater. Biol. Appl. 2016, 58, 294-309. [CrossRef] [PubMed]

14. Karaszewska, A.; Kamińska, I.; Kiwała, M.; Gadzinowski, M.; Gosecki, M.; Slomkowski, S. Preparation and properties of textile materials modified with triclosan-loaded polylactide microparticles. Polym. Adv. Technol. 2017, 28, 1185-1193. [CrossRef]

15. Goetzendorf-Grabowska, B.; Polus, Z.; Kiwała, M.; Karaszewska, A.; Kamińska, I.; Mączka, I. Antibacterial air filter nonwovens modified by poly(lactide) microspheres containing triclosan. Fibres Text. East. Eur. 2015, 23, 114-119.

16. McDonnell, G.; Russell, A.D. Antiseptics and disinfectants: Activity, action, and resistance. Clin. Microbiol. Rev. 1999, 12, 147-179. [CrossRef]

17. Cooper, R. A review of the evidence for the use of topical antimicrobial agents in wound care. World Wide Wounds 2004. Available online: http://www.worldwidewounds.com/2004/february/Cooper/TopicalAntimicrobial-Agents.html (accessed on 1 February 2004).

18. Sibbald, R.G.; Leaper, D.J.; Queen, D. Iodine Made Easy. Wounds Int. 2011, 2. Available online: http: //www.woundsinternational.com (accessed on 1 May 2011).

19. Moulay, S. Molecular iodine/polymer complexes. J. Polym. Eng. 2013, 33, 389-443. [CrossRef]

20. Moulay, S. Macromolecule/polymer-iodine complexes: An update. Rec. Innov. Chem. Eng. 2019, 12, $174-233$. [CrossRef]

21. Immel, S.; Lichtenthaler, F.W. The hydrophobic topographies of amylose and its blue iodine complex. Starch 2000, 52, 1-8. [CrossRef]

22. Klimaviciute, R.; Bendoraitiene, J.; Rutkaite, R.; Siugzdaite, J.; Zemaitaitis, A. Preparation, stability and antimicrobial activity of cationic cross-linked starch-iodine complexes. Int. J. Biol. Macromol. 2012, 51, 800-807. [CrossRef] [PubMed]

23. Bendoraitiene, J.; Sarkinas, A.; Danilovas, P.P.; Rutkaite, R.; Klimaviciute, R.; Zemaitaitis, A. Cationic starch iodophores. J. Appl. Polym. Sci. 2013, 128, 4346-4354. [CrossRef]

24. Tang, Y.; Xie, L.; Sai, S.; Xu, N.; Ding, D. Preparation and antibacterial activity of quaternized chitosan with iodine. Mat. Sci. Eng. C 2015, 48, 1-4. [CrossRef] [PubMed]

25. Hamblin, M.R. Antimicrobial photodynamic inactivation: A bright new technique to kill resistant microbes. Curr. Opin. Microbiol. 2016, 33, 67-73. [CrossRef]

26. Kashef, N.; Huang, Y.Y.; Hamblin, M.R. Advances in antimicrobial photodynamic inactivation at the nanoscale. Nanophotonics 2017, 6, 853-879. [CrossRef]

27. Vieira, C.; Gomes, A.T.P.C.; Mesquita, M.Q.; Moura, N.N.M.; Neves, M.G.P.M.S.; Faustino, A.F.; Almeida, A. An insight into the potentiation effect of potassium iodide on APDT efficacy. Front. Microbiol. 2018, 9, 2665. [CrossRef]

28. Ghaffari, S.; Sarp, A.S.K.; Lange, D.; Gulsoy, M. Potassium iodide potentiated photodynamic inactivation of Enterococcus faecalis using toluidine blue: Comparative analysis and post-treatment biofilm formation study. Photodiagnosis Photodyn. Ther. 2018, 24, 245-249. [CrossRef]

29. Huang, Y.Y.; Wintner, A.; Seed, P.C.; Braun, T.; Gelfand, J.A.; Hamblin, M.R. Antimicrobial photodynamic therapy mediated by methylene blue and potassium iodide to treat urinary tract infection in a female rat model. Sci. Rep. 2018, 8, 7257. [CrossRef]

30. Santos, A.R.; Batista, A.F.P.; Gomes, A.T.P.C.; Neves, M.G.P.M.S.; Faustino, M.A.F.; Almeida, A.; Hioka, N.; Mikcha, J.M.G. The remarkable effect of potassium iodide in eosin and rose bengal photodynamic action against Salmonella typhimurium and Staphylococcus aureus. Antibiotics 2019, 8, 211. [CrossRef]

31. Kubát, P.; Henke, P.; Mosinger, J. The effect of iodide and temperature on enhancing antibacterial properties of nanoparticles with an encapsulated photosensitizer. Colloids Surf. B Biointerfaces 2019, 176, 334-340. [CrossRef]

32. Huang, L.; Szewczyk, G.; Sarna, T.; Hamblin, M.R. Potassium iodide potentiates broad-spectrum antimicrobial photodynamic inactivation using photofrin. ACS Infect. Dis. 2017, 3, 320-328. [CrossRef] [PubMed]

33. Xuan, W.; He, Y.; Huang, L.; Huang, Y.Y.; Bhayana, B.; Xia, L.; Gelfand, J.A.; Hamblin, M.R. Antimicrobial Photodynamic Inactivation mediated by tetracyclines In Vitro and In Vivo: Photochemical mechanisms and potentiation by potassium iodide. Sci. Rep. 2018, 8, 17130. [CrossRef] 
34. Hamblin, M.R.; Abrahamse, H. Inorganic salts and antimicrobial photodynamic therapy: Mechanistic conundrums. Molecules 2018, 23, 3190. [CrossRef] [PubMed]

35. Azimzadehirani, M.; Elahifard, M.R.; Haghighi, S.; Gholami, M.R. Highly efficient hydroxyapatite/TiO 2 composites covered by silver halides as E. coli disinfectant under visible light and dark media. Photochem. Photobiol. Sci. 2013, 12, 1787-1794. [CrossRef]

36. Huang, Y.-Y.; Choi, H.; Kushida, Y.; Bhayana, B.; Wang, Y.; Hamblin, M.R. Broad-spectrum antimicrobial effects of photocatalysis using titanium dioxide nanoparticles are strongly potentiated by addition of potassium iodide. Antimicrob. Agents Chemother. 2016, 60, 5445-5453. [CrossRef]

37. Deng, W.; Ning, S.; Lin, Q.; Zhang, H.; Zhou, T.; Lin, H.; Long, J.; Lin, Q.; Wang, X. I-TiO $2 / P V C$ film with highly photocatalytic antibacterial activity under visible light. Colloids Surf. B Biointerfaces 2016, 144, 196-202. [CrossRef] [PubMed]

38. Kida, N.; Mochizuki, Y.; Taguchi, F. An effective iodide formulation for killing Bacillus and Geobacillus spores over a wide temperature range. J. Appl. Microbiol. 2004, 97, 402-409. [CrossRef] [PubMed]

39. Tonoyan, L.; Fleming, G.T.A.; Mc Cay, P.H.; Friel, R.; O’Flaherty, V. Antibacterial potential of an antimicrobial agent inspired by peroxidase-catalyzed systems. Front. Microbiol. 2017, 8, 680. [CrossRef]

40. Tonoyan, L.; Boyd, A.; Fleming, G.T.A.; Friel, R.; Gately, C.M.; Mc Cay, P.H.; O’Flaherty, V. In vitro comparative cytotoxicity study of a novel biocidal iodo-thiocyanate complex. Toxicol. Vitro 2018, 50, 264-273. [CrossRef]

41. Punyani, S.; Singh, H. Preparation of iodine containing quaternary amine methacrylate copolymers and their contact killing antimicrobial properties. J. Appl. Polym. Sci. 2006, 102, 1038-1044. [CrossRef]

42. Zainul Abid, C.K.V.; Jackeray, R.; Jain, S.; Chattopadhyay, S.; Asif, S.; Singh, H. Antimicrobial efficacy of synthesized quaternary ammonium polyamidoamine dendrimers and dendritic polymer network. J. Nanosci. Nanotechnol. 2016, 16, 998-1007. [CrossRef] [PubMed]

43. Martins, A.F.; Facchi, S.P.; Follmann, H.D.M.; Pereira, A.G.; Rubira, A.F.; Muniz, E.C. Antimicrobial activity of chitosan derivatives containing N-quaternized moieties in its backbone: A review. Int. J. Mol. Sci. 2014, 15, 20800-20832. [CrossRef] [PubMed]

44. Kudzin, Z.H.; Depczynski, R.; Kudzin, M.H.; Luczak, J.; Drabowicz, J. 1-(N-Trifluoroacetyl-amino)alkylphosphonic acids: Synthesis and properties. Amino Acids 2007, 33, 663-667. [CrossRef] [PubMed]

45. Kudzin, Z.H.; Depczyński, R.; Kudzin, M.H.; Drabowicz, J. 1-(N-chloroacetylamino)-alkylphosphonic acids-Synthetic precursors of phosphonopeptides. Amino Acids 2008, 34, 163-168. [CrossRef]

46. Drabowicz, J.; Jakubowski, H.; Kudzin, M.H.; Kudzin, Z.H. The nomenclature of 1-aminoalkylphosphonic acids and derivatives: Evolution of the code system. Acta Biochim. Pol. 2015, 62, 139-150. [CrossRef]

47. Kudzin, Z.H.; Kudzin, M.H.; Drabowicz, J.; Stevens, C.V. Aminophosphonic acids-phosphorus analogues of natural amino acids. Part 1: Syntheses of $\alpha$-aminophosphonic acids. Curr. Org. Chem. 2011, 15, 2015-2071. [CrossRef]

48. Drabowicz, J.; Jordan, F.; Kudzin, M.H.; Kudzin, Z.H.; Stevens, C.V.; Urbaniak, P. Reactivity of aminophosphonic acids. Oxidative dephosphonylation of 1-aminoalkylphosphonic acids by aqueous halogens. Dalton Trans. 2016, 45, 2308-2317. [CrossRef]

49. Cypryk, M.; Drabowicz, J.; Gostynski, B.; Kudzin, M.H.; Kudzin, Z.H. Urbaniak, P.1-(Acylamino)alkyl-phosphonic acids-Alkaline deacylation. Molecules 2018, 23, 859. [CrossRef]

50. Sójka-Ledakowicz, J.; Kudzin, M.H. Effect of plasma modification on the chemical structure of a polyethylene terephthalate fabrics surface. Fibres Text. East. Eur. 2014, 22, 118-122.

51. Sójka-Ledakowicz, J.; Łatwińska, M.; Kałuzka, J.; Kudzin, M. Polypropylene nonwovens with natural polymers addition for filtration applications. Polymers 2013, 58, 557-561. [CrossRef]

52. Kudzin, M.H.; Mrozińska, Z.; Walawska, A.; Sójka-Ledakowicz, J. Biofunctionalization of textile materials. 1. Biofunctionalization of poly(propylene) (PP) nonwovens fabrics by Alafosfalin. Coatings 2019, 9, 412. [CrossRef]

53. Kudzin, M.H.; Mrozińska, Z. Biofunctionalization of Textile Materials. 2. Antimicrobial modification of poly(lactide) (PLA) nonwoven fabrics by fosfomycin. Polymers 2020, 12, 768. [CrossRef]

54. Kudzin, M.H.; Mrozińska, Z.; Urbaniak, P.; Drabowicz, J. Phosphorylation of Cellulose, P-128. In Proceedings of the 19th International Symposium Advances in the Chemistry of Heteroorganic Compounds, Łódź, Poland, 12 October 2016. CBMM PAN \& CHF UŁ. 
55. EN ISO 9237:1998 standard. Textiles-Determination of Permeability of Fabrics to Air; International Organization for Standardization: Geneva, Switzerland, 1998.

56. EN ISO 10319:2015-08 standard. Textiles-Test methods for nonwovens-Part 3: Determination of tensile strength and elongation.

57. EN 14119: 2005 point 10.5 (B2) standard. Testing of textiles-Evaluation of the action of microfungi-Visual method.

58. Jia, L.; Prabhakaran, M.P.; Qin, X.; Ramakrishna, S. Stem cell differentiation on electrospun nanofibrous substrates for vascular tissue engineering. Mater. Sci. Eng. C 2013, 33, 4640-4650. [CrossRef] [PubMed]

59. Matysiak, W.; Kapica, A.; Tański, T.; Dubiel, A. Analysis of the influence of electro spinning process parameters on the morphology of poly(lactic acid) fibres. Archiv. Mater. Sci. Eng. 2019, 96, 73-78. [CrossRef]

60. Krucińska, I.; Surma, B.; Chrzanowski, M.; Skrzetuska, E.; Puchalski, M. Application of melt-blown technology in the manufacturing of a solvent vapor-sensitive, non-woven fabric composed of poly(lactic acid) loaded with multi-walled carbon nanotubes. Text. Res. J. 2013, 83, 859-870. [CrossRef]

61. Zhang, J.; Chen, G.; Bhat, G.S.; Azari, H.; Pen, H. Electret characteristics of melt-blown polylactic acid fabrics for air filtration application. J. Appl. Polym. Sci. 2020, 137, 48309. [CrossRef]

62. Zhu, F.; Yu, B.; Su, J.; Han, J. Study on PLA/PA11 bio-based toughening melt-blown nonwovens. Autex Res. J. 2020, 20. [CrossRef]

63. Kister, G.; Cassanas, G.; Vert, M. Effects of morphology, conformation and configuration on the IR and Raman spectra of various poly(lactic acid)s. Polymer 1998, 39, 267-273. [CrossRef]

64. Grabowska, B.; Holtzer, M. Structural examination of the cross-linking reaction mechanism of polyacrylate binding agents. Arch. Metal. Mater. 2009, 54, 427-438.

65. Vrandečić, N.S.; Erceg, M.; Jakić, M.; Klarić, I. Kinetic analysis of thermal degradation of poly(ethylene glycol) and poly(ethylene oxide)s of different molecular weight. Thermochim. Acta 2010, 498, 71-80. [CrossRef]

66. Snavely, D.L.; Dubsky, J. Near-IR spectra of polyethylene, polyethylene glycol, and polyvinylethyl ether. J. Polym. Sci. Part A Polym. Chem. 1996, 34, 2575-2579. [CrossRef]

67. Fang, J.F.; Xuan, Y.M.; Li, Q. Preparation of polystyrene spheres in different particle sizes and assembly of the PS colloidal crystals. Sci. China Tech. Sci. 2010, 53, 3088-3093. [CrossRef]

68. Singh, M.; Singh, V.K.; Surana, K.; Bhattacharya, B.; Singh, P.K.; Rhee, H.W. New polymer electrolyte for electrochemical application. J. Ind. Eng. Chem. 2012, 19, 819-822. [CrossRef]

69. NIST Standard Reference Database 69: NIST Chemistry WebBook; Coblentz Society, Inc.; Coblentz No. 10116. Available online: https://webbook.nist.gov/chemistry/ (accessed on 6 April 2020).

70. Jiang, L.; Wang, F.; Han, F.; Prinyawiwatkul, W.; No, H.K.; Ge, B. Evaluation of diffusion and dilution methods to determine the antimicrobial activity of water-soluble chitosan derivatives. J. Appl. Microbiol. 2012, 114, 956-963. [CrossRef]

71. Balouiri, M.; Sadiki, M.; Ibnsouda, S.K. Methods for in vitro evaluating antimicrobial activity: A review. J. Pharm. Anal. 2016, 6, 71-79. [CrossRef] [PubMed]

(C) 2020 by the authors. Licensee MDPI, Basel, Switzerland. This article is an open access article distributed under the terms and conditions of the Creative Commons Attribution (CC BY) license (http://creativecommons.org/licenses/by/4.0/). 